\title{
The Concept of "Value" in the Theory of Marketing
}

\author{
Roman Sidorchuk ${ }^{1}$ \\ ${ }^{1}$ Department of Marketing, Plekhanov Russian University of Economics, Moscow, Russian Federation \\ Correspondence: Roman Sidorchuk, Department of Marketing, Plekhanov Russian University of Economics, \\ Moscow, Russian Federation. Tel: 8-499-237-9496. E-mail: Sidorchuk.RR@rea.ru
}

Received: January 2, 2015 Accepted: January 28, 2015 Online Published: April 2, 2015

doi:10.5539/ass.v11n9p320 URL: http://dx.doi.org/10.5539/ass.v11n9p320

\begin{abstract}
This paper discusses the use of the term of "value" in the framework of marketing. Analysis of the literature led us to the conclusion that it is necessary to consider the term of "value" in the framework of marketing as a separate category of marketing theory, which includes a whole group of concepts. The basis for our findings served as the analysis of the definition of "value" in the disciplines included in the multi-disciplinary marketing database. The paper suggests that the price is not a marketing measure for "value". In addition, the paper outlines further research aimed at the development and systematization of the concepts included in the category of "value" in marketing.
\end{abstract}

Keywords: value in marketing, category of marketing, definition of marketing, marketing theory

\section{Introduction}

Discussion on considering marketing as an independent science has a long history. Specific features of marketing, such as its applied nature, dualism, significant methodological apparatus borrowed from other disciplines come as a barrier when considered as an independent discipline. At the same time, further development of marketing, including the application of its importance as an academic discipline, requires further discussion on the relation of art and science in marketing.

Extensive discussions about marketing as a science started in the 40s of the 20th century, and although major publications were made at 60-70 years, this debate is still going on. (Converse, 1945; Alderson \& Cox, 1948, Bartels, 1951; Buzzell, 1964; Taylor, 1965; Hunt, 1976, 1983; O'Shaughnessy \& Ryan, 1979; Kotler, 1972; Gummesson, 2002; Golubkov, 2003). Despite a slight decrease the intensity of the discussion, the issues related to marketing science or art continues to occupy minds of researchers. We consider marketing as a science and, as an important aspect; this discussion will focus on discussing the use of the term of "value" in marketing.

\section{Literature Review}

Some studies show that the analysis of the concept of "value" reveals terminological complexity (Repev, 2010). Especially, we shall highlight the use synonymous concept to both term of "value" and "customer value" in the Russian marketing.

The analysis of the descriptions of the terms in the dictionaries for marketing shows that, for example, the glossary by the American Marketing Association (www.commonlanguage.wikispaces.net) ignores the definition of "value". The description contains the terms of "Customer Lifetime Value" and "Economic Profit", which can be treated as one of the names of net operating profit after taxation. In turn, the Russian dictionary of terms for "Marketing", the term of "value" is identified with the utility and benefits to consumers (Golubkov, 2003).

The paper by Porter, "Competitive Advantage", offers the methodology of the possible competitive advantages analysis through a chain of benefit when "the company's operations are divided into the strategically important activities in order to examine the costs and the existing and possible means of differentiation". In this paper, the value also assumes the identity of utility, where the price is its main criterion (Porter, 1985). This approach can be seen in many modern papers (Feller, Shunk, \& Callarman, 2006; Nikolaev, 2009; Meshcheriakova, 2010)

In turn, this identity is not unique in the description of the concept of "Marketing 3.0.". (Kotler, Kartavadzhayya, \& Setiawan, 2012) point the term of "value" as the key concept; describe the current state of information technology and social cultural and personal space related to it. However, at the same time, a clear definition of this term is not provided. In fact, the authors refer to only a certain region of the senses for the concept. 
Prahlad and Ramaswamy in their paper (2006) also describe the space for creating "value" for the consumer, but avoid its clear definition.

A similar situation is shown in the paper by Throsby (2013). Realizing the obvious importance of the term of "value", he devotes a whole chapter to it. However, despite the interesting analysis and conclusions made by the author, in the end, he did not formulate own definition of the term of "value", but only describes the features of this concept in the cultural space.

In turn, the paper by Neganova (2012) describes different approaches to the term of "value". In this case, in addition to the term of "value" and "customer value" the author cites in this regard some other terms: "customer value", "value of buyers", etc. At the same time, in spite of the comparative analysis of different definitions, the author does not lead us to the logical structure and the relationship of these terms.

There are papers (Hakseve, Chaganti, \& Cook), considering the value not only through the value for the consumer ("customer value"), but also more broadly, encompassing the ability of a product, service or activity to satisfy the need to provide any utility to a human being, organization, and society. For example, based on models of value creation, in one of the papers by (Ivashkova, 2013), there is an attempt to determine the costs and utilities specific to shareholders, employees, customers, suppliers, and society. At that, the author demonstrates an important feature: the difference in value estimates of various social groups in relation to one product. Some papers consider the concept of value through the applications of loyalty programs (Sidorchuk, 2014) or in the implementation of the marketing function in museums (Sidorchuk \& Grineva, 2014).

The above analysis of the literature demonstrates that there is a need in the structuring of terminological apparatus of marketing associated with the term of "value".

\section{Limitations and Methods for the Research}

In our study, we are based on the desk research methodology using the content analysis method. At the heart of our discussion is the concept of marketing as a combined interdisciplinary theory. The basis of this theory (marketing), according to Bartels (1976) is on economic, psychological, and sociological theories in all their relationships. At the same time, we believe that it is necessary to consider that marketing is a separate area of knowledge and application of practical methods and conceptual approaches from other disciplines shall not be confused with the area of disciplinary conceptual marketing. In addition, we do not assume in our study to delve into the analysis of value approaches of these subjects, but at the same time, we believe it is necessary to use in the analysis of the provisions of the axiological philosophy theory.

\section{Results of the Study}

First, it is necessary to make structural clarity between the terms of "value", "customer value" and others. The basis for the logic of their relationship is the terms of "concept" and "category". We are based on the definition of the term of "category" as the most general and fundamental concept which is the form and stable organizing thinking principle, i.e. fundamental scientific concept reflecting the most general properties and connection of the reality and cognition (Philosophy: Encyclopedic Dictionary, ed. Ivina, 2004). In turn, the term of "concept" is a common name with a relatively clear content and a relatively well-defined volume.

Values mean a general category, in which, as rightly pointed out in several studies, various directions are possible (Neganova, 2012). In various papers, the value is reduced to norms, ideals, and utility (Dokuchaev, 2006). Thus, we expect to distinguish the following categories: "Values" and "Values in various disciplines", including marketing (Figure 1).

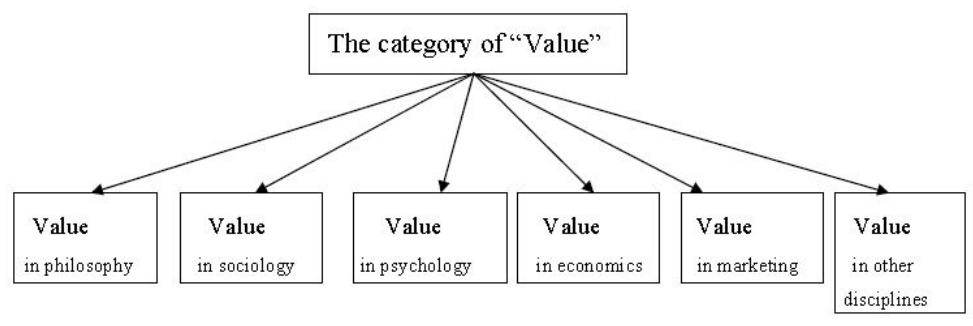

Figure 1. Category Tree named "Values"

Below, we briefly consider the category of "value" for the disciplines related to multidisciplinary database of marketing. 
Philosophy often regards value as the "relationship between the representation of the subject on the valued object and the object itself" (Philosophy: Encyclopedic Dictionary, ed. Ivina, 2004). However, the interpretation of the term is not limited to the above, which allows considering it as a category.

From the point of view of psychology, the category of "value" is based on the psychological nature of a human being and can be viewed from the standpoint of determining the notion of "understood value", "value, as a form of social relations" and bringing these positions with the motivation (Leontiev, 2003). Interpretation of the "understood value", which corresponds to a certain extent to the concepts of "opinion" and "belief", does not have the self-motivating force. The concept of "value" as a form of social relations, that is a kind of structuring function of the individual's conduct, does not have the motivating force as well. In our opinion, marketing is interested in approach combining these two approaches, bringing them closer to the motivating force. In general, such diversity in the definition of "value" allows it to be considered in psychology as a separate category.

In turn, in the sociology, the term of "value" is usually considered in the framework of a social group. One definition of the term of "value" treats it as "any item that has empirical content, available to members of the social group, as well as value, due to which it is or may be subject to action" (Thomas \& Znaniecki, 1976). In contrast to the above definitions for philosophy and psychology, sociology puts the value as if "taken out" beyond the individual framework.

In economics, the "value" is identified with utility. The basis is the following prerequisite - people choose the goods and services assessed at the highest level. Scientific theory here is the concept of marginal utility. At that, Samuelson (1997) notes that the utility - "is not feelings, available for measurement, but a scientific concept". It is believed that with the gradual saturation of the needs of a subject, the utility of goods or services falls. It is also assumed that with the growth of goods consumption (at constant consumption volume of all others), the total value received by the consumer is increasing even more slowly. In addition, the main measure of the utility is price. Despite the fact that in our opinion, the economic theory is the main for marketing, we do not assume for the definitions of "value" and "customer value" for a more in-depth analysis of the theory of marginal utility and its ordinal and cardinal (quantitative) directions and proceed directly to the category of "value in marketing".

Initially, it shall be noted that there is a difficulty in using a linguistic term of "value" in marketing. In the English literature, the term of "value" often means "cost" or "value-added cost" that makes some terminological confusion. Therefore, "a number of English-speaking authors propose to use the term of added value agent in marketing, focusing on the values of the subjective factor" (Golubkov, 2012).

In the early papers on marketing, the term of "value" in the sense that distinguishes it from the "price" is practically non-existent. This follows, for example, from the analysis of the paper by Bartels (1976). Table 1 shows the definition of the value in the marketing literature.

Table 1. Definition of the term of "value" in the framework of marketing

\begin{tabular}{|c|c|}
\hline Authors & Definition \\
\hline Schechter, 1984 & $\begin{array}{l}\text { Value means all factors that make up the overall shopping experience: quantitative and } \\
\text { qualitative, subjective and objective }\end{array}$ \\
\hline Lambin, 1996 & $\begin{array}{l}\text { A more practical alternative is the concept of "perceived value of the goods to the buyer", } \\
\text { based on full knowledge and understanding of the end-use of the product }\end{array}$ \\
\hline Doyle, 2001 & Value is a consumer's assessment of the ability of a product or service to meet their needs \\
\hline \multirow[t]{3}{*}{ Gordon, 2001} & $\begin{array}{l}\text { Value of the buyers is determined according to the average annual value of the buyers in the } \\
\text { category under which each of them falls, to the projected lifetime of the customers as the } \\
\text { buyers and to projected changes in the volume of their purchases over time. }\end{array}$ \\
\hline & $\begin{array}{l}\text { Value may be viewed in relation to the characteristic features of the following two } \\
\text { categories: a) signs describing the functions that goods carry; }\end{array}$ \\
\hline & b) emotional and other non-functional features covered by a trademark \\
\hline $\begin{array}{l}\text { Gamble, Stone, } \\
\text { Woodcock, } 2002\end{array}$ & $\begin{array}{l}\text { The first element of consumer value is the monetary aspect; the second element is the } \\
\text { additional cost of the consumer to receive the benefits that interest them; the third element is } \\
\text { the value that the consumer receives in exchange for the money paid }\end{array}$ \\
\hline $\begin{array}{l}\text { Winer, Lehmann, } \\
2004\end{array}$ & $\begin{array}{l}\text { From a consumer perspective, this is the value of the goods, or the consumer value, i.e. how } \\
\text { valuable this product is for the consumer. }\end{array}$ \\
\hline
\end{tabular}




\begin{tabular}{ll}
\hline Authors & Definition \\
\hline $\begin{array}{l}\text { Economic value for the consumer (EVC) is a pure value in monetary terms (savings) } \\
\text { obtained by the use of certain goods (often - new) instead of the corresponding substitute } \\
\text { (the one that is currently in use). EVC is the difference between the values of the total direct } \\
\text { costs of using the two competing products. Consumer value (value) is the cost of a product } \\
\text { or service to the consumer in monetary terms }\end{array}$
\end{tabular}

Webster, 2005 The key point in the strategy of positioning is what we call the proposition of the value. This concept describes the way in which the company delivers value to its target customers. However, it is important to remember that the value is determined by the customers, so the perception of it changes according to their needs, the nature of the decision-making process on the purchase (and, more importantly, in accordance with the composition of members of the buying process), and competitive offerings.

Kotler, Keller, The value reflects the perceived tangible and intangible benefits and costs of the buyer; it 2006 can be represented as a combination of quality, service, and price (CVT - "customer value triad")

Payne, 2007 The value obtained by the client is a set of benefits that he/she takes from the main product or service of the company.

Consumer value is the result of maximum value to the customer with the deployment of updated strategies to attract and retain customers and using effective distribution channels management.

Shareholder value is made up of a favourable rate of return on invested capital

Grönroos, 2007 The value is considered as the main object of exchange. The value is the result of evaluation by the buyer with the seller

Neganova, 2012 Products and services have value, which is created by the company based on consumer demand outside markets, and markets exchange that value between the producer and the consumer. In this regard, the marketing specialists and managers are focused on the formation of an effective value chain, logistics, product quality control, etc.

With the advent of the value chain model by Porter (1985), the term of "value" in the sense of "customer value" started its avalanche spread in the literature. At the same time, it caused some criticism in the use of the term. Thus, Ramsay writes: "What kind of chain did Porter mean? Personally, I have no any idea. All these talks of the value chain are misleading". Then "The value seems quite an abstract phenomenon, and therefore it is impossible to deliver or to offer or to receive or to describe using verbs which are used for handling concrete things. Consequently, the value cannot be passed from department to department... Imagine a company that sells the product, but there is a competitor with the best offer. Our sales are falling severely. It turns out that their products had a "value" before, but then lost it". (Ramsay, 2005). Repev (2010) agrees with this point of view: "A practical marketing specialist is unlikely to apply such concepts as "deliver value", "customer's value", "value proposition", "value design". Such criticism of using the term "value" is true. The problem with using the term of "value" is clearly observed, for example, in the field of culture and culturally based products (Sidorchuk \& Grineva, 2014)

\section{Conclusions}

The above considerations allow us to draw the following conclusions: The current uncertainty in the use of the term of "value" due to the fact that the severity of the definition of "concept" is replaced by polysemy of "category". This leads to ambiguities in the use of the term of "value" as appropriate or personal interpretation, irrespective of the content of the marketing theory and its multidisciplinary base. In addition, there is a tendency, when the term of "value" is widely used in studies on marketing, but researchers just rely on one or another definition, using it as an operational one and analyse its conceptual importance in the theory of marketing. At the same time, the above-shown analysis of papers allows us to suggest that if the economic theory of the "value" category identification with effectiveness is justified, and the price may be a measure of this effectiveness, this issue is quite different from the point of view of marketing. According Lamben, “... a company can no longer remain insensitive to the demands of social responsibility". (Lamben, 1996) In its turn, the paper by Nikishkin (2012) demonstrated that the analysis of entrepreneurial activity in the world for a long period showed that at average life cycle of an enterprise of 10-20 years, the longer life cycle is peculiar with enterprises oriented at humanistic values. Further 
arguments put the question: how can one say about the usefulness of tobacco, alcohol with the point of view of social responsibility? In addition, there are goods and services, which value for individuals, social groups, or society can be infinitely large, while the price has a definite size. For example, the price (cost) of many paintings is defined in their insurance policies, while their value to society commensurate with the amount entered. Here again we come back to the above-mentioned paper by Throsby (2013). He writes: "It can be argued that market prices are at best an imperfect indicator for values behind them". Further: "...prices do not reflect the additional consumer pleasure experienced when purchasing a product". In this regard, we see that the theory of marketing "value" shall be considered as a category, which includes a whole range of concepts (e.g., "consumer value", "customer's value", etc.).

Therefore, based on the idea of "value" as a category of marketing, it can be determined as follows: the value (in marketing) is the perfect model of obtaining satisfaction from the result (the process) the exchange of goods and services to individual consumers, social groups, companies or associations, which determines the their stable basic life orientation and motivational setting. It shall be noted that we distinguish between the terms of "value in marketing" and "marketing value".

Our formulated definition of the category of "value" in marketing will allow for the systematization of the conceptual apparatus of terms related to this category. We see the prospect of further work not only in the development of theoretical definitions, but also in the field and desk research aimed at understanding the patterns and the allocation of obtaining satisfaction indicators, determining the stability of basic life guidance and motivation to set different groups of consumers, companies and society as a whole.

\section{References}

Alderson W., \& Cox R. (1948). Towards a theory of marketing. Journal of Marketing, 10(October), 1-34.

Andrew, F., Shunk, D., \& Callarman, T. (n. d.). Value Chains Versus Supply Chains. Retrieved January 12, 2014, from http://www.bptrends.com/publicationfiles/03-06-ART-ValueChains-SupplyChains-Feller.pdf

Bartels, R. (1951). Can marketing be a science?. Journal of Marketing, 51(January), 319-28. http://dx.doi.org/10.2307/1247368

Bartels, R. (1976). The History of Marketing Thought (2nd ed.). GRID INC. Columbus. Ohio.

Buzzell, R. D. (1964). Is marketing a science?. Harvard Business Review, 4l(1), 32-40.

Converse, P. D. (1945). The development of the science of marketing: An exploratory study. Journal of Marketing, 10(July), 1-34.

Customer Lifetime Value. Retrieved January 12, 2014, from http://www.commonlanguage.wikispaces.net/ Customer+Lifetime+Value

Dokuchaev, I. I. (2009) Tsennost and existential. Fundamental principle of the historical culture of axiology. $S$. $P b .:$ Science, 595.

Doyle, P. (2001). Management strategy and tactics. SPb.: Peter.

Economic Profit. Retrieved from http://www.commonlanguage.wikispaces.net/Economic+Profit\#EVA

Gamble, P., Stone, M., \& Woodcock, N. (2002). Marketing relationships with consumers. Moscow: Fair Press.

Golubkov, E. P. (2003). On some concepts and terminology of marketing. Marketing in Russia and abroad, 5 , 3-13.

Golubkov, E. P. (2012). Marketing. Glossary of terms (p. 320). M.: Case and service.

Gordon, J. (2001). Marketing partnerships. SPb.: Peter.

Grönroos, C. (2007). Service management and marketing: customer management in service competition (3rd ed.). Christian Grönroos. John Wiley \&Sons Inc.

Gummesson, E. (1999). Total Relationship Marketing. Butterworth-Heinemann.

Haksever, C., Chaganti, R., \& Cook, R. G. A. (2004). Model of Value Creation: Strategic View. Journal of Business Ethics, 49. http://dx.doi.org/10.1023/B:BUSI.0000017968.21563.05

Hunt, S. D. (1976). Marketing Theory: Conceptualizations of Research in Marketing. Ohio: Grid Publishing.

Hunt, S. D. (1983). Marketing Theory: The Philosophy of Marketing Science. Illinois: Richard D. Irvvm, Inc.

Ivashkova, N. I. (2013). Modern marketing concept of creating value for consumers, businesses and society. Bulletin of the Russian Economic University, 8(62), 91-100. 
Ivin, A. A. (Ed.). (2004). Philosophy: Encyclopedic Dictionary. Retrieved from http://dic.academic.ru/dic.nsf/ enc_philosophy $/ 952 / \% \mathrm{D} 0 \% 9 \mathrm{~F} \% \mathrm{D} 0 \% 9 \mathrm{E} \% \mathrm{D} 0 \%$ 9D\% D0\% AF\% D0\% A2\% D0\% 98\% D0\% 95

Kotler P. A. (1972). Generic Concept of Marketing. Journal of Marketing, 36(April), 46-54. http://dx.doi.org/10.2307/1250977

Kotler, F., Kartadzhayya, H., \& Setiawan, A. (2012). Marketing 3.0: From Products to consumers and then the human soul (p. 240).

Kotler, P. A., \& Keller, K. (2006). Marketing management. Prentice Hall.

Lambin, J.-J. (1996). Strategic Marketing. European perspective, 15, 589. SPb., Nauka.

Leontiev, D. A. (2014). Psychology of meaning: the nature, structure and dynamics of the sense of reality. Retrieved from http://lib.rus.ec/b/438033/read

Meshcheriakova, N. S. (2010). Analysis of the concept of "utility" and "value" of the goods in marketing as applied economics. Economic Sciences and Humanities, 11(226), 137-144.

Neganova, V. P. (2012). Category value in relationship marketing. Marketing and reklama, 3(41), 122-127.

Nikishkin, V. V. (2012). The innovative concept of marketing as a response to the challenges of the modern world. Practical marketing, 12(178), 4-7.

Nikolaev, A. M. (2009). Customer value as a structure factor of the marketing mix. Journal of Economic teorii, 3, 23-31.

Payne, A. (2007). Handbook of CRM: Achieving Excellence in Customer Management. Minsk: Grevtsov.

Porter, M. E. (1985). Competitive Advantage: Creating and Sustaining Superior Performance. NY: Free Press.

Prahlad, K. K., \& Ramaswamy, V. (2006). Future competition. Creating a unique value with customers (p. 352).

Ramsay, J. (2005). The real meaning of value in trading relationships. International Journal of Operations \& Production Management, 25(6), 549-565. http://dx.doi.org/10.1108/01443570510599719

Repev A. P. (n. d.). Value (value), USP and selling points. Retrieved from http://www.repiev.ru/articles/ Value.htm

Ryan, M. J., \& O'Shaughnessy, J. (1982). Scientific Explanation and Technological Prediction. In R. Bush, \& S. Hunt (Eds.), Marketing Theory: Philosophy of Science Perspectives (pp. 22-25). Chicago: American Marketing Association.

Samuelson, P. A. (1997). Economics. Moscow, BINOM, Laboratory base znaniy.

Schechter, L. (1984). A Normative Conception of Value. Progressive Grocer, Executive Report, 12-14.

Sidorchuk, R. (2014). Integral Effect Estimation Methods for a Partner Company of the Participation in the Coalition Loyalty Program. Research Journal of Applied Sciences, 9, 947-951. http://dx.doi.org/10.3923/ rjasci.2014.947.951

Sidorchuk, R., \& Olga, G. (2014). Research for the marketing state in Russian museums. Review of European Studies, 6(4). http://dx.doi.org/10.5539/res.v6n4p283

Taylor, W. J. (1965). Is Marketing a Science? Journal of Marketing, 29(3), 49-53. http://dx.doi.org/10.2307/ 1248545

Thomas, W., Znaniecki, F., \& Chlop, P. W. (1976). Europe I Ameryce (p. 387). Warsawa: Lud. Spolds. Wyd.

Throsby, D. (2013). Economics of culture (p. 256).

Webster, F. E., Jr. (2005). Industrial marketing strategy. Moscow: Publishing House of Grebennikov.

Winer, R., \& Lehmann, D. (2004). Product Management. Moscow: ID Williams.

\section{Copyrights}

Copyright for this article is retained by the author(s), with first publication rights granted to the journal.

This is an open-access article distributed under the terms and conditions of the Creative Commons Attribution license (http://creativecommons.org/licenses/by/3.0/). 